IRSH 52 (2007), pp. 373-406 DOI: I0.1017/S0020859007003045

(C) 2007 Internationaal Instituut voor Sociale Geschiedenis

\title{
The Consumer Movement and Civil Society in Malaysia
}

\author{
MatThew Hilton
}

Summary: This paper examines the consumer movement in Malaysia, especially the Consumers' Association of Penang and the Federation of Malaysian Consumer Associations. It traces their history from the late I960s, through a period of rapid social and economic change associated with the New Economic Policy of the r 970 s and I980s. Partly because of the absence of other NGOs in Malaysia (due to government clampdowns on civil society), consumer groups were able to take a prominent position and to develop socio-political campaigns on behalf of the poor and the disadvantaged. This proved an inspiration to consumer organizing globally, especially in the developed world, but it is not clear that consumerism as a social movement can be sustained. Since the mid-I980s, other NGOs have emerged, eclipsing the influence of consumerism, and promoting a human rights agenda which has overtaken the politics of consumption as the dominant oppositional rhetoric of non-governmental groups.

\section{INTRODUCTION}

In the latter half of the twentieth century the international consumer movement became one of the most significant non-governmental organizations (NGOs) operating in global civil society. Beginning in the United States prior to World War II, organizations engaged in the comparative testing of different branded products and the advocacy of consumer rights flourished in Europe in the 1950s. In 1960, several of these organizations came together to form the International Organization of Consumers' Unions (IOCU), an organization which has both promoted the spread of consumer movements around the world as well as representing consumer interests in international agencies such as the United Nations (UN). ${ }^{\mathrm{I}}$

One of the more remarkable aspects of IOCU's development has been its incorporation of the interests of developing-world consumers. IOCU has come to defend the interests of all consumers, not only promoting their

I. Foo Gaik Sim, IOCU on Record: A Documentary History of the International Organisation of Consumers Unions, 1960-1990 (New York, I99I); Matthew Hilton, Consumerism in Twentieth-Century Britain: The Search for a Historical Movement (Cambridge, 2003), ch. I I. 
ability to shop more rationally, but advocating the right of everybody to have access to basic needs: necessity, rather than luxury, became the defining focus of the international consumer movement from the midI970s. Of crucial importance to this shift in emphasis of organized consumerism was the spread of the consumer movement into Asia. While an Indian consumer movement had emerged as early as 1956 (the Indian Association of Consumers), thereby pre-dating many European consumer movements, and consumerism became rapidly established in Japan, Australia, and New Zealand, south-east Asian consumerism began with the formation of the Consumers' Federated Groups of the Philippines in 1963. This was followed by the Selangor Consumers' Association in 1965, the Consumers' Association of Penang in 1969, the Consumer Association of Singapore in I97I, the Philippine Consumers' Movement in 197I, and the Indonesian Consumers' Organization in $1973 .^{2}$

Crucial to the international movement, however, were the developments in Malaysia. It was there that in 1974 IOCU established its first regional office (for the Asia-Pacific area) in Penang, and it did so deliberately to build on the strengths of the organized consumer movement already existing on the island. Indeed, the first regional director of IOCU was Anwar Fazal, one of the founders of the Consumers' Association of Penang (CAP). A case study of Malaysian consumer activism is therefore pertinent as it not only casts light on international consumer agendas, but provides an important focus on consumer organizing in a state where various restrictions were placed on civil society. Although citizens in Europe and North America have organized as consumers to defend the needs of the poor (as in the consumers' cooperative movement), since World War II organized consumerism has been usually associated with the affluent purchasing decisions of subscribers to such testing magazines as Consumer Reports, Which?, Que Choisir?, Consumentengids, and Test. What is not generally known is that consumer activism has been a prominent force around the world in countries where one might expect citizens to have had other interests that needed defending than those stemming from being a consumer. It is the intention of this essay, therefore, to explain the historical development of consumerism in Malaysia in order to cast light on the phenomenon of developing-world consumerism more generally.

To do so, the article begins with a discussion of the state and civil society in Malaysia. What is apparent is the inapplicability of strict definitions of civil society and non-governmental organizing to non-Western contexts

2. Josie Fernandez, "Consumer Protection in Asia: The Challenges Ahead", Journal of Development Communication, I 2 (200I), pp. 42-52; Josie Fernandez, "Asian-Pacific Consumer Movement", in S. Brobeck, R.N. Mayer, and R.O. Herrmann (eds), Encyclopaedia of the Consumer Movement (Santa Barbara, CA, 1997), pp. 38-42; John T.D. Wood, "Consumer Protection in the Asian-Pacific Region”, Journal of Consumer Policy, I4 (199I), pp. 99-106. 
such as those found in south-east Asia, especially in the I970s and I980s. Following the lead of existing scholarship, it accordingly argues that Malaysian civil society cannot be understood without reference to the state; nor can it be understood without an appreciation of the often inevitable "consensual and collaborative dimensions" that mark the relationship between the federal government and a range of actors with varying degrees of independence. Nevertheless, despite such a sociopolitical environment, a consumer movement has operated in Malaysia and a second section details its history over the last thirty to forty years. It is based on a comprehensive analysis of all the printed primary publications of the three main consumer organizations in Malaysia, as well as interviews with a number of consumer leaders, conducted by the author and by the British journalist, Jeremy Seabrook. ${ }^{3}$

What it finds is that because of the restrictions on more contentious civil society groups, Malaysian consumer activists were often the first to mobilize on a whole spectrum of problems affecting the poor during a process of economic development. The CAP especially sought to address a range of social and economic issues free from the ethnic communalism which pervaded so many aspects of party political life. ${ }^{4}$ In seeking out common citizenship issues it preceded many of the other organizations more typically associated with civil society today, be they gender-based, youth-focused, or concerned primarily with human rights. Yet consumerism emerged not simply as a means of addressing questions of citizenship under a different title, but because the meaning of consumerism - and, hence, being a consumer - proved particularly appealing to a generation of Malaysians dealing with the rapid changes instigated by the New Economic Policy of the I970s and I980s.

However, Malaysian consumerism is not without its problems and divisions. A third section will therefore deal with the role of the state in Malaysian consumerism, a presence which has created a clear split in the movement. On the one hand, there has been the CAP, which has vigorously defended its financial independence, at the cost of coming under the attention of the internal security forces. On the other hand, other state consumer groups within Malaysia's federal structure have received direct government financial assistance. The Federation of Malaysian Consumer Organizations was an attempt at cooption by the state, but as with other "non-state" actors in Malaysia, this should not blind us to the activities, agendas, achievements, and issues raised by these

3. I am extremely grateful to Jeremy Seabrook for making his notes available to me. Other sources include internal consumer organization documents when available (tropical climate permitting) and the private papers of a number of consumer activists who kindly lent me their materials.

4. The population is roughly io per cent Indian, one-third Chinese, and just over one-half Malay. 
only partially independent groups. The employment of strict definitions of civil society and "non-governmental organization" (NGO) in our analysis will only exclude from our studies important dimensions to socio-political action in countries such as Malaysia.

Indeed, recent definitions of NGOs provided by the international community reflect the problematic nature of defining NGOs in the developing world. In order to overcome these problems, many organizations within the international community have adopted an all-inclusive approach. The United Nations Economic and Social Council, for instance, refers to an NGO as "any organization that is not established by an agreement among governments".s Others, however, have emphasized either the voluntary nature of NGO memberships or the progressive dimension of the work: the World Bank, for instance, refers to "organizations that pursue activities to relieve suffering, promote the interests of the poor, protect the environment, provide basic social services, or undertake community development" ${ }^{6}$ For the purposes of this paper, the definition of an NGO is not so all-inclusive so as to include businesses and trade unions (as in the ECOSOC definition), but it does embrace the campaigning criteria of the World Bank, though it does not assume that these have to be progressive. It does not include a whole wider range of civil-society organizations which do not adopt an overtly political or campaigning role, such as sports and recreational clubs, but it does accept that organizations which receive funds from governments can still be categorized as NGOs so long as they can legitimately claim to be independent. ${ }^{7}$

The prominence of the consumer movement in Malaysia is due not only to its adoption of a number of radical consumer causes, but because it operated for much of its time in a relatively uncluttered arena of nongovernmental activity. However, since the ig8os other NGOs have expanded enormously, eclipsing the once prominent role CAP had in particular. A fourth section of this essay will examine the role of consumerism in relation to other social movements, focusing on the period since the late 1980 s when human rights NGOs began to dominate. Indeed, the consumer movement's more recent attention to questions of economic, social, and cultural rights reflects the hegemony of human rights language in civil society more generally. In this regard, Malaysian consumerism has come to follow the lead of other NGOs rather than providing the lead for them as it had done in its heyday prior to the I 980 . The essay therefore offers some reflections on the relevance of consumer

5. A. Iriye, Global Community: The Role of International Organizations in the Making of the Contemporary World (Berkeley, CA, 2002), p. 2.

6. See website: http://docs.lib.duke.edu/igo/guides/ngo/define.htm (accessed January 2007).

7. For further definitions of NGOs (as well as some of the problems involved), I refer readers to my project on a database of the archives of NGOs: www.bham.dango.ac.uk/Dango.Defining.htm 
organizations to Malaysian civil society today. It suggests the historical specificity of consumerism as a social movement to a particular period of Malaysian economic and social development.

However, this should not blind us to the fact that the consumer movement developed a very different politics of consumption than that articulated by Western consumer groups. A final, concluding section will therefore assess the impact of Malaysian and developing world consumerism on global consumer-citizen concerns. This, in turn, will raise questions about the nature of consumer protest at the global level, demonstrating that both necessity and affluence have been key concerns of international consumerism, a factor missing in all other accounts of the organized consumer movement of the post-World-War-II period.

\section{CIVIL SOCIETY IN MALA YSIA}

Before we can analyse the role of the consumer movement in Malaysia it is necessary to understand the nature of both Malaysian civil society and the impact of the federal state. There has been no room for a discussion of the consumer movement in existing accounts of either sphere. Yet Malaysian consumerism played a dominant role in social and political action in the I 970 s and I 980 s, long before the opening up and expansion of civil society actors from the mid-I980s. Undoubtedly, this was as much to do with the assumed political neutrality of a movement of consumers as it was to do with any intrinsic abilities and qualities of the consumer movement itself: the consumer movement was tolerated and even encouraged by a state which saw an opportunity to direct public anger away from more hostile opposition groups. But this should not prevent a recognition that consumerism as a socio-political movement did emerge and in many ways provided the leadership for a fledgling community of non-governmental actors.

Until relatively recently the debate as to the nature of civil society in Malaysia has been overshadowed by the discussion of the authoritarian nature of the federal government. Constitutionally, Malaysia has remained a democratic country, but the power of the political elites and the stranglehold of the United Malays' National Organisation (UMNO) and the Barisan Nasional (National Front) on public life has led one scholar to label the regime "semi-authoritarian". ${ }^{8}$ This is an interpretation with which several others have broadly concurred, ${ }^{9}$ although Malaysian

8. Harold Crouch, "Malaysia: Neither Authoritarian nor Democratic", in Kevin Hewison, Richard Robinson, and Garry Rodan (eds), Southeast Asia in the 1990s: Authoritarianism, Democracy and Capitalism (Sydney, NSW, 1993), pp. I33-I 58.

9. William Case, "Semi-Democracy in Malaysia: Withstanding the Pressures for Regime Change", Pacific Affairs, 66 (1993), pp. I83-205; Zakaria Haji Ahmad, "Malaysia: QuasiDemocracy in a Divided Society", in Larry Diamong, Juan J. Linz, and Seymour Martin Lipset (eds), Democracy in Developing Countries, vol. 3 (Boulder, CO, 1989). 
scholars such as Edmund Terence Gomez and Jomo K.S. have disputed such compromises and identified the government of Dr Mahathir bin Mohamad (198I-2003) in particular as determinedly "authoritarian", especially because of the clampdowns on civil society and political opposition. ${ }^{\mathrm{IO}}$

Indeed, Malaysian governments have borrowed and adapted many of the repressive measures first introduced under British colonialism. ${ }^{\text {II }}$ The I960 Internal Security Act (ISA), which enables detention without trial, was further bolstered by the Societies Act of 1966 placing limits upon civil society organization and, following the watershed racial riots of 1969 when a state of emergency was called, further measures were introduced such as the Sedition Act of I971 and the Official Secrets Act of 1972. Under Mahathir's leadership, these were amended, updated, and extended, as in the Printing Presses and Publications Act of $1988 .{ }^{12}$ Throughout the I970s, ISA continued to be used to detain political insurgents (including the future Deputy Prime Minister, Anwar Ibrahim), yet by the I980s the government drew upon it less frequently, enabling groups such as the CAP and the human rights NGO and reform think tank, Aliran (Aliran Kesedaran Negara, or National Consciousness Movement) to expand. ${ }^{13}$ However, in 1987, Operasi Lallang saw the arrest and detention of over Io० political opponents of Mahathir, including a number of civil society leaders. Many were released over the subsequent I 8 months, but the ISA has still loomed as a very real threat over Malaysian civil society during the last Io to I 5 years. Indeed, it was resorted to again in the late I990s at the height of the economic crisis, in $200 \mathrm{I}$ just before and after the II September attacks on the World Trade Centre, and, most infamously, in 1998, when Anwar Ibrahim himself was detained, to be later tried and imprisoned on trumped up charges of sodomy.

Such repressive forms of legislation can have profound impact on the development of NGOs. Clearly, it is difficult to speak of NGOs in a society where organizations are subject to such strong state intervention. For instance, the Societies Act requires that all NGOs are registered with the Registrar of Societies. This was amended in 198 I by a further Act which required their categorization into "friendly" and "political" societies, which meant the latter found it difficult to obtain foreign

ı. Edmund Terence Gomez and Jomo K.S., Malaysia's Political Economy: Politics, Patronage and Profits (Cambridge, i997), p. 3.

I I. T.N. Harper, The End of Empire and the Making of Malaya (Cambridge, I999).

I 2. Joel S. Kahn and Francis Loh Kok Wah, "Introduction: Fragmented Vision", in Joel S. Kahn and Francis Loh Kok Wah (eds), Fragmented Vision: Culture and Politics in Contemporary Malaysia (Sydney, NSW, I992), pp. I-I7.

I 3. Harold Crouch, "Authoritarian Trends, the UMNO Split and the Limits of State Power", in Kahn and Loh, Fragmented Vision, pp. 2 I -43 . 
funding and could employ only certain categories of people. ${ }^{\mathrm{I}}$ Only a public outcry led to the dilution of these measures in 1983 , but it is sufficient evidence to demonstrate the state's attitudes to civil society. Only in more recent years, with the rise of Reformasi, has civil society launched a more concerted attack against the strands of authoritarianism. ${ }^{\text {Is }}$

Yet the state continues to maintain a troubled attitude to civil society. On the one hand, it has sought to contain and coopt NGOs with the establishment of its own issue-based organizations and institutions such as the National Human Rights Commission, Subakam, upon which sit several NGO leaders. On the other, it still persists in harassing civil society leaders, such as Irene Fernandez, the head of Tenaganita, who was prosecuted under the Printing Presses and Publications Act for publishing a memorandum on the treatment of migrant workers at detention camps, leading to the longest trial in Malaysian history. ${ }^{16}$ Other institutions necessary for the free operation of civil society have faced similar pressures. Radio and television in Malaysia are effectively government monopolies and the newspapers are party-affiliated. ${ }^{17}$ While the control of the state is far from total in these fields, these restrictions nevertheless create a very different theatre of operations for organized consumerism than in the West, relying as it does on freedom of information as a fundamental human right.

Furthermore, the dynamics of civil society in countries such as Malaysia cannot be understood without reference to race. ${ }^{18}$ The response to the racial riots of 1969 only increased the racialized nature of Malaysian politics, not least because of the affirmative-action policies of the NEP, which have granted special privileges to ethnic Muslim Malays or bumiputera (sons of the soil). If Mahathir was temporarily ejected from UMNO for stirring up ethnic tension in his The Malay Dilemma, the focus on ethnicity and the promotion of Malay nationalism was soon at the heart of UMNO policy, especially in their I97 I manifesto, Revolusi Mental, which heralded the coming of the NEP. ${ }^{19}$ The government

14. Lim Teck Ghee, "Non-Governmental Organisations in Malaysia and Regional Networking", in Tadashi Yamamoto (ed.), Emerging Civil Society in the Asia Pacific Community: Nongovernmental Underpinnings of the Emerging Asia Pacific Regional Community (Singapore, I996), pp. 165-i 82.

I 5. Khoo Boo Teik, Beyond Mahathir: Malaysian Politics and its Discontents (London, 2003), p. I I; Bridget Welsh (ed.), Reflections: The Mahathir Years (Baltimore, MD, 2004).

16. Vidhu Verma, Malaysia: State and Civil Society in Transition (Petaling Jaya, 2004), p. 175. 17. Crouch, "Authoritarian Trends", p. 25; Graham Brown, "The Rough and Rosy Road: Sites of Contestation in Malaysia's Shackled Media Industry", Pacific Affairs, 78 (2005), pp. 39-56. I8. Edmund Terence Gomez (ed.), The State of Malaysia: Ethnicity, Equity and Reform (London, 2004).

19. Mahathir Bin Mohamad, The Malay Dilemma (1970; Kuala Lumpur, 2003). For an excellent critique of Mahathir's racialism see Syed Hussein Alatas, The Myth of the Lazy Native: A Study of the Image of the Malays, Filipinos and Javanese from the 16th to the 20th Century and its Function in the Ideology of Capitalism (London, 1977). 
response to the events of 1969 , therefore, not only led to a repression of civil society, but to the further entrenchment of race and communalist party politics within Malaysian socio-political discourse and practice. ${ }^{20}$ Indeed, in his study of rural peasant responses to economic development policies James C. Scott described the pervasive nature of the party political system within Malaysian society. Faced with fundamental changes to their rice growing practices, the villages of Scott's case study turned not to civil society and social welfare organizations, which simply did not exist, but to the two dominant political parties of the region, UMNO and the Islamic Party of Malaysia. ${ }^{21}$

Given such measures and practices, it is therefore all the more remarkable that civil society has developed at all in Malaysia, if not the entire south-east Asian region as a whole. Within the Association of Southeast Asian Nations, NGOs developed largely among the literate, urban middle classes and, just as in Malaysia, have extended their activities in spite of their operation under various authoritarian regimes. ${ }^{22}$ In Malaysia, civil-society organizations have their origins in the final years of the colonial regime, when a diverse range of philanthropic bodies, rate-payer groups, Rotary Clubs, educational clubs, reform organizations, and religious associations were set up to engage in a public debate as to the planning and meaning of the identity of independent Malaya. ${ }^{23}$ For Meredith Weiss and Saliha Hassan, these early "moral communities" - concerned as they often were with the defence of traditional ways of life - gave way to NGOs in the I 970 s as issues became more focused and politicized. ${ }^{24}$

Here, what is meant by NGOs are those groups operating as much as possible independently of the state and having as one of their goals the reform of a specific part of society or politics. They constitute a form of political opposition in Malaysian society, though the nature of this opposition does not always have to be radical, utopian, or ideological. But, importantly, they represent a new form of socio-political engagement. Up to the I970s, it has been argued, political opposition in south-east Asia was dominated by peasant insurgencies, student protest, and radical underground movements. These were suppressed and only with the democratization of authoritarian regimes in the 1980 s did new forms of political

20. Barbara Watson Andaya and Leonard Y. Andaya, A History of Malaysia (Honolulu, HA, 200I); Harper, End of Empire; Ziauddin Sardar, The Consumption of Kuala Lumpur (London, 2000); Kahn and Loh, "Introduction" in idem, Fragmented Vision.

2 I. James C. Scott, Weapons of the Weak: Everyday Forms of Peasant Resistance (New Haven, CT, 1985$)$.

22. Lim Teck Ghee, "Non-Government Organisations", p. 170.

23. Harper, End of Empire, pp. 224-225.

24. Meredith L. Weiss and Saliha Hassan, "Introduction: From Moral Communities to NGOs", in idem (eds), Social Movements in Malaysia: From Moral Communities to NGOs (London, 2003), p. 4 . 
engagement emerge. These were tied in with the social and economic changes brought about by industrialization, especially in the creation of an urban middle class which provided the membership of organizations based upon the protection of human rights or the defence of women's interests. ${ }^{25}$

This was certainly the case in Malaysia: political opposition based upon subversive insurgency has given way to reform promoted by a whole range of NGOs. But what such an interpretation misses is the continued and ongoing activities of social welfare agencies. A key set of organizations therefore excluded from existing accounts of Malaysian politics and associational life are the consumer groups which came to prominence in the I970s, long after the radicalism of peasant, labour, and student movements, but long before the explosion of NGO activity since the midI980s. Instead, the literature has focused on the women's movement, the human rights movement, environmental protectionism, and the growth of Islamic organizations, especially as they have emerged since the I980s. These works replicate the distinction between an earlier generation of civil society organizations associated with post-independent Malaya and the activist campaigning NGOs of the I980s.

Thus, for instance, in the women's movement, attention is given to the National Council of Women's Organizations, created in I961, which went on to act as the principal welfare, religious, and service-oriented group of middle- and upper-class women. But then academic attention has shifted to the more overtly politicized and feminist organizations of the I $980 \mathrm{~s}$, such as the Women's Aid Organization (I982), the Women's Crisis Centre (I982), the All-Women's Action Society (I 985 ), and Sisters in Islam (1992). ${ }^{26}$ Such a distinct periodization of NGO activity might apply to the history of women's rights, but it ignores the activities of consumerism in the intervening period. Similarly, with regard to human rights, the establishment of Aliran in 1977 is acknowledged, sometimes regarded as the "lynchpin of Penang's NGO community", but it is seen mainly as a forerunner of the huge expansion of human-rights NGOs in the I 980 , from Suara Rakyat Malaysia (Suaram, Voice of the Malaysian People) to the National Human Rights Society of Malaysia (Hakam) and a whole range of other NGOs which united around a Malaysian Charter on Human Rights. ${ }^{27}$

25. Garry Rodan, "Theorising Political Opposition in East and Southeast Asia”, in idem, Political Oppositions in Industrialising Asia (London, I996), pp. I-39.

26. Lai Suat Yan, “The Women's Movement in Peninsular Malaysia, 1900-1999: A Historical Analysis", in Weiss and Hassan, Social Movements in Malaysia, pp. 45-74.

27. Kua Kia Soong, Malaysian Critical Issues (Petaling Jaya, 2002); Suaram, Working for Human Rights (Kuala Lumpur, 2003); Kua Kia Soong, "Malaysian Communities Resist: A Critique of Malaysian Development", in idem (ed.), People Before Profits: The Rights of Malaysian Communities in Development (Petaling Jaya, 200I), pp. I-I2; Meredith L. Weiss, "The Malaysian Human Rights Movement", in Weiss and Hassan, Social Movements in Malaysia, pp. I $40-164$. 
Again, in studies of environmentalism, there is a distance between the socially conservative Malayan Nature Society, set up in the I940s, and the more aggressive Worldwide Fund for Nature Malaysia and the Environmental Protection Society of Malaysia formed in the I970s. These campaigning groups actually predated many of the human rights organizations, although it is generally overlooked that one of the most prominent, Sababat Alam Malaysia (SAM, Friends of the Earth Malaysia), is the direct sister organization of the CAP. ${ }^{28}$ In fact, the only sector of the current NGO community of Malaysia which has received in-depth attention in the transitional period of the I970s is the Islamic sector. In that decade, the Malaysian Islamic Youth Movement was created, presided over by Anwar Ibrahim from I 974 to I982. It has attempted to promote what it regarded as a proper understanding of Islam, opposing Malaysia's reliance on the international economic system as well as many of the symbols of Westernization such as alcohol and gambling. ${ }^{29}$

The existence of such a range of NGOs does not, however, imply the existence of an independent civil society equivalent to - or comparable with - the one which has been said to exist in the West. Vidhu Verma has recently traced the blurring of the boundaries of state and civil society in Malaysia through the granting of special privileges to the Malays at independence and in the New Economic Policy. Furthermore, the state has promoted its own private organizations and taken over existing ones such that, today, "Malaysia has many formal institutions of democracy and organization, but they do not enjoy autonomy from the state, are not based on a rule of law, and do not respond to the needs and interests of civil society." $3 \circ$ Sheila Nair more directly challenges any attempts to understand Malaysian civil society from western liberal models which do not pay heed to the "consensual and collaborative dimensions" of the Malaysian experience which has meant NGOs have played a role in "the production of political ideology and practice". ${ }^{\text {I }}$ She instead views civil society as an arena in which non-government actors "can be theorised as forms of resistance to a dominant ideological discourse centred around official constructions". ${ }^{2}$ Certainly, this is in line with Tim Harper's

28. Sundari Ramakrishna, "The Environmental Movement in Malaysia”, in Weiss and Hassan, Social Movements in Malaysia, pp. I I $5-139$.

29. Chandra Muzaffar, "Islamic Resurgence and the Question of Development in Malaysia", in Lim Teck Ghee (ed.), Reflections on Development in Southeast Asia (Singapore, 1988), pp. I-25, I I; Saliha Hassan, "Islamic Non-Governmental Organisations", in Weiss and Hassan, Social Movements in Malaysia, pp. 97-Ir4; Gordon P. Means, Malaysian Politics: The Second Generation (Singapore, 1991).

30. Verma, Malaysia, p. I60.

3r. Sheila Nair, "Constructing Civil Society in Malaysia: Nationalism, Hegemony and Resistance”, in Jomo K.S. (ed.), Rethinking Malaysia (Kuala Lumpur, 1999), pp. 84-106.

32. Ibid., p. 84 . 
argument that the Malaysian state has never been able to control resistance and such controls only give rise to ever more avenues for opposition. ${ }^{33}$

But it is, perhaps, futile to seek clear manifestations of civil society in such a country as Malaysia, especially since the term itself is more often used as an ideal type than a lived reality. Garry Rodan has urged us to focus less on the dilemmas of civil society versus the state and acknowledge instead that the social and economic changes of rapid industrialization have created new forms of political space. He argues that "the state versus civil society dichotomy should not be rigidly enforced if we are trying to conceptualize the full range of political contestations in any society, particularly one-party states or 'dominant party systems' which characterize much of East and Southeast Asia". ${ }^{34}$ Certainly, this is the case in Malaysia, where too much of a focus on state-civil-society relations ignores the forms of activism and reform that have taken place. On specific issues, NGOs have been able to influence political discourse in a manner which exceeds their seemingly repressed status, and civil society (however problematically defined) in Malaysia can be argued to be a small yet not insignificant political space which has managed to maintain an independence from a highly centralized and controlling state.

What this means is that there is a definitional and an historical aspect of civil society. Of the former, there has been a clear expansion since the I 980 s and the entry of a number of organizations, some of which are easily identifiable as "non-governmental" and others which are less so but which have still contributed to Malaysian public life. Of the historical aspect, it needs to be re-emphasized just how important consumer activism has been in bridging the acknowledged gap between an insurrectionary radical politics of the immediate post-independence decades and the increase in the number of organizations - radical, reformist, conservative, and even coopted - which have flourished amidst the democratization of the regime associated with the last twenty years. Consumerism, as it emerged in the late I960s, might better be understood as one of the earliest movements in a new generation of non-party political activism. It has worked closely with other NGOs and provided a leadership to them.

Consumer groups often provided the training for a generation of social activists who emerged in the I980s, such as Tenaganita's Irene Fernandez, who had previously served as the secretary of the Selangor Consumers' Association. It has often set the agenda for other campaign areas, as with environmentalism. And consumer groups have contributed to the Malaysian debate on human rights, having seen some of its activists detained

33. Harper, End of Empire, p. 382.

34. Rodan, "Theorising Political Opposition", p. 28. See also Saskia Sassen, "The Repositioning of Citizenship: Emergent Subjects and Spaces for Politics", The New Centennial Review, 3:2 (2003), pp. 4I-66. 
without trial in the 1987 crackdown on civil society, and later participating in government forums such as Subakam (National Human Rights Commission). In this regard, consumerism has added to the consensual nature of official ideology, yet in its opposition to the government's development agenda, it has been as much a force for civil society resistance (as defined by Nair and Harper), as any other human rights, environmental, women's, or radical religious NGO. A study of Malaysian consumerism is therefore important, not only because it casts light on assumptions about consumer activism in the West, but because it corrects an omission within debates about civil society in south-east Asia. And it is precisely these restrictions on national civil society which explain the direction of consumer activism in Malaysia which, in turn, came to re-direct much of the thinking and practice of the international consumer movement.

\section{THE HISTORY OF MALAYSIAN CONSUMERISM}

The first moves to create a consumer movement in Malaysia began in December 1964, with the establishment of the Penang Consumers' Association, an organization set up by the MP Dr Lim Chong Eu (a former president of the MCA and later a member of the opposition party, Gerakan) to campaign against high prices on the island. 35 Unable to keep members interested, the association never progressed beyond its first meeting, though it inspired a number of professionals, teachers, and civil servants to create an equivalent body, the Selangor Consumers' Association (SCA) in Kuala Lumpur just one month later. ${ }^{36}$ Initially prompted by the concern of middle-class Malaysians with the cost of newspaper delivery charges, the SCA soon went on to adopt many of the classic concerns associated with the consumer movements of western Europe and North America. By the end of the i960s, it had begun a complaints service, it was publishing its own magazine, Berita Pengguna (Consumer News), and it was giving talks to schools, rotary clubs, and other bodies typical of capital city associational life. It had begun to engage in some rudimentary forms of product testing and it was developing its membership base to consist of around 2,000 white-collar workers, two-thirds of whom were male. Furthermore, many were located in prominent positions around the city and had links to the Selangor Chief Minister as well as federal government departments which looked favourably upon this fledgling consumer movement as a means to educate consumers to support Malaysian industry and to assist in the efficient running of the market. ${ }^{37}$

35. Mahmuda Bibi, "A Short Note on the Early History of the Consumer Movement in Malaysia”, unpublished paper, 2003 (private papers of Anwar Fazal).

36. Mohd Hamdan Adnan, Understanding Consumerism (Petaling Jaya, 2000), p. 60.

37. SCA, First Conference on Consumer Action in Malaysia, Kuala Lumpur, 24 February 1968

(Kuala Lumpur, 1968); SCA, Annual Reports and Accounts, 1967 (Kuala Lumpur, I968); SCA, 
In 1969, SCA officials went on to assist in the creation of the CAP, where individuals such as Anwar Fazal had recently been organizing meetings and exhibitions on consumer topics, inspired by the example of Ralph Nader in the United States. Further momentum to the formation of CAP came with the racial riots following the election in May, an event which both freed up the time of the unsuccessful UMNO candidate, S.M. Mohamed Idris, and focused the minds of the liberal urban middle classes on the means by which social and economic issues could be addressed outside the party political system, and which had the potential to unite Malaysians of all races behind common causes ("transethnic solidarities" as Sumit Mandal refers to them). ${ }^{38}$ CAP would go on to be the most successful of all Malaysian consumer groups, if not of the entire developing world, yet at the time of its formation it represented just one more success in a campaign to create consumer organizations in all the states of Malaysia. From 1969 the SCA Vice-President, Syed Adam Al-Ja'fri, travelled around the country and established consumers groups in many of Malaysia's individual states. ${ }^{39}$

The next logical stage was to develop a national federation of consumer groups. CAP proposed a National Consumer Council and liased with the SCA throughout I $970-\mathrm{I} 97 \mathrm{I} .{ }^{40}$ But at this time government scrutiny of the SCA's activities had led to a formal protest and the resignation of the entire SCA committee. As a means of highlighting the abusive powers of the police and the state, the SCA plan backfired, since it enabled a new committee to be elected, far more amenable to the interests of business and much more willing to work with government, including the seeking of financial support and the consequent loss of independence. CAP, emphasizing the importance of complete consumer independence, refused to negotiate further with the SCA in the formation of a consumer federation and the impetus therefore shifted to the federal state. The Ministry of Commerce and Industry believed it would be useful to have a movement with which to link up, particularly in the areas of prices and containing inflation. ${ }^{4 \mathrm{I}}$ In June 1973 , a meeting of the existing consumers' associations was held in Alor Setar, Kedah and the Federation of

Consumer Trade Fair, Kuala Lumpur, 7-12 April 1970 (Kuala Lumpur, 1970); SCA, Annual Report, 1969 (Kuala Lumpur, 1970).

38. Interview with Anwar Fazal, I3 April 2004; interview with Anwar Fazal, conducted by Jeremy Seabrook, I7 July 1997; University of Malaya Graduates' Society of Penang, press release, October 1969 (private papers of Anwar Fazal); CAP, Ist Annual Report, 1969-1970 (Penang, I97I); Bibi, "A short note [...]", p. 2; Interview with S.M. Mohamed Idris, I6 April 2004; Sumit Mandal, "Transethnic Solidarities, Racialisation and Social Equality", in Gomez, The State of Malaysia, 49-78.

39. SCA, Annual Report, 1969 (Kuala Lumpur, 1970), p. 59.

40. Utusan Konsumer, I (June I97I), p. 3; Bibi, “A short note [...]", p. 3; Utusan Konsumer, 2 (July I971), p. 3.

4I. Interview with Anwar Fazal, i7 April 2004; Bibi, "A short note [...]”, p. 3. 
Malaysian Consumers' Associations (FOMCA) was formed under the leadership of Mohamed Sopiee, Malaysia's Director of Information.

FOMCA was therefore formed through the direct initiative of the government, helped on a practical level by the new secretary of the SCA who had, in any case, close links with that government. ${ }^{42}$ In many ways it was a clear instance of state cooption since it brought under its umbrella an expanding movement that had a potential oppositional character but which could now be contained within it. Many within the consumer movement, though, prefer to stress the existence of several independent associations prior to the formation of FOMCA, suggesting that the federation was as much a grassroots movement as it was a top-down initiative. Yet, for CAP, the links between FOMCA and the government have remained too close and to this day CAP has never joined the Federation. It constitutes a split in the consumer movement which reflects the dilemmas facing NGOs operating in the type of civil society discussed in the previous section. One trajectory of Malaysian consumerism has therefore followed an independent path - and consequently can better claim to be "non-governmental" - while the other has chosen to work with the state believing complete independence can only result in a complete lack of influence.

But, regardless of what would later be termed the "thorny embrace" between FOMCA and the government, consumerism did become one area of focus for oppositional politics in the I970s, contributing to those forms of resistance to dominant official ideologies and practices. ${ }^{43}$ CAP's immediate focus was on core consumer issues - consumer education, complaints handling, exposing market abuses, pressing for protective legislation - but its officers soon realized "the potential power of this movement". ${ }^{44}$ CAP could fight for a basic consumer injustice, such as the use of a prawn paste, Blachan, adulterated with the toxin Rhodomine-B, and then appeal to all consumers, rich and poor alike, since the flavouring was a staple of Malaysian cooking. ${ }^{45}$ CAP realized - to a far greater extent than in the West - that there were two types of consumer in Malaysia - the poor and the rich - and that different interests arose accordingly and had to be dealt with in different ways. It meant that CAP's operating activities expanded incrementally in the I970s, moving from one specific issue to the next, while at the same time extrapolating from the particular to comment on the general issues facing all consumers and the structural causes which prevented the poor from having the same access to consumer rights and opportunities as the rich.

42. Josie M. Fernandez, Contested Space? FOMCA's Engagement with the Government (Petaling Jaya, 2004), p. v; Lim Teck Ghee, "Non-Governmental Organisations in Malaysia".

43. The phrase "thorny embrace" is taken from Fernandez, Contested Space.

44. Interview with Anwar Fazal, conducted by Jeremy Seabrook, i7 July 1997.

45. Utusan Konsumer, 7 (February-March 1972), p. I. 
Very soon after its formation CAP was addressing a range of issues which questioned the model of development then being pursued by the Malaysian government. It began to turn its attention to the activities of multi-national corporations and it asked questions about the effects of modernization on the environment. ${ }^{46}$ It questioned the "colossal waste of public funds" diverted to prestige projects such as the construction of Penang Bridge. ${ }^{47}$ And it identified problems which would become not only the celebrated issues of Malaysian consumerism, but the rallying points for an expanding global civil society in the I970s and I980s such as the marketing of inappropriate breast-milk substitutes and the inadequate regulation of pesticides (as set out in the Pesticides Act of 1974).48 These campaigns represent what Jeremy Seabrook has claimed has been the "organic" growth of CAP:

[...] it has listened to and responded to the needs of the people [...] as these have arisen; it has facilitated and supported popular resistance as and when it has been asked to do so. This is how the critique of development has evolved - not according to theory or any preconceived idea of what development is or is not, but by weighing the effects of this or that project on the people who are supposed to be the beneficiaries or who turn out to be disadvantaged by it. 49

Here was a model of consumerism that took account of not only the interests of individual shoppers but the concerns of those seemingly excluded from the consumer society supposedly being built in their name. And here was a model of social and economic engagement of tremendous appeal to a rising generation of Malaysian activists. When interviewed, CAP staff have attested to the appeal of an organization which presented an alternative form of development based on a different value framework than one found in the "money-driven" consumer society..$^{\circ}$ And CAP's activities, as expressed in its newspaper, Utusan Konsumer, were attractive to a wider population concerned with both the strengths and weaknesses of the development: that is, they appreciated CAP's concerns with basic consumer issues but admired too the focus on people not able to share in the rising consumption patterns. ${ }^{\text {II }}$ Sales of Utusan Konsumer had reached 25,000 by I $98 \mathrm{I}$ and 40,000 just 4 years later, a figure all the more

46. Utusan Konsumer, I4 (January-February 1974), p. 2.

47. Utusan Konsumer, I6 (June-August 1974), p. I.

48. Utusan Konsumer, I7 (September-December 1974), p. 5.

49. Jeremy Seabrook, "The Consumers' Association of Penang”, unpublished manuscript, I998, p. I. I am extremely grateful to Jeremy Seabrook for making his papers on CAP, as well as his interviews with CAP officials, available to me.

50. Interview with Evelyn Hong, conducted by Jeremy Seabrook, I99[?]; interview with Mary Assunta, conducted by Jeremy Seabrook, 24 March I998; interview with Subbarow, conducted by Jeremy Seabrook, I99[?]; interview with Lim Teck Ghee, conducted by Jeremy Seabrook, 20 May 1998; interview with Lim Jee Juan, conducted by Jeremy Seabrook, I 998.

51. Utusan Konsumer, 59 (June 1979), p. I3. 


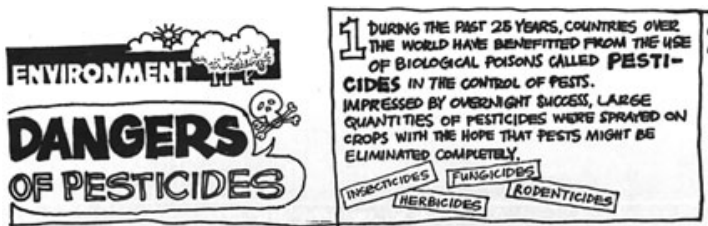

Q However peopue Besin To eEluze THUT 23 PESTICIDES IS ONIY A SHORT TEEM SOLUTON To PEST CONIROL \& FOR nis BeVEFT iT CONFES, MANY DISIONAWTAGES MAY RESULT FROM IIS USE. THEY KIL PESTS. THEY kTU CEEATURES WHICA EAT TIE POISONEP PESTS, THEY KILL LARGGR CREATURES WHICH EAT NHE

AS YOU ARE READING THIS, YOU ALSO HAVE PESTICIDES IN YOUR BODY.

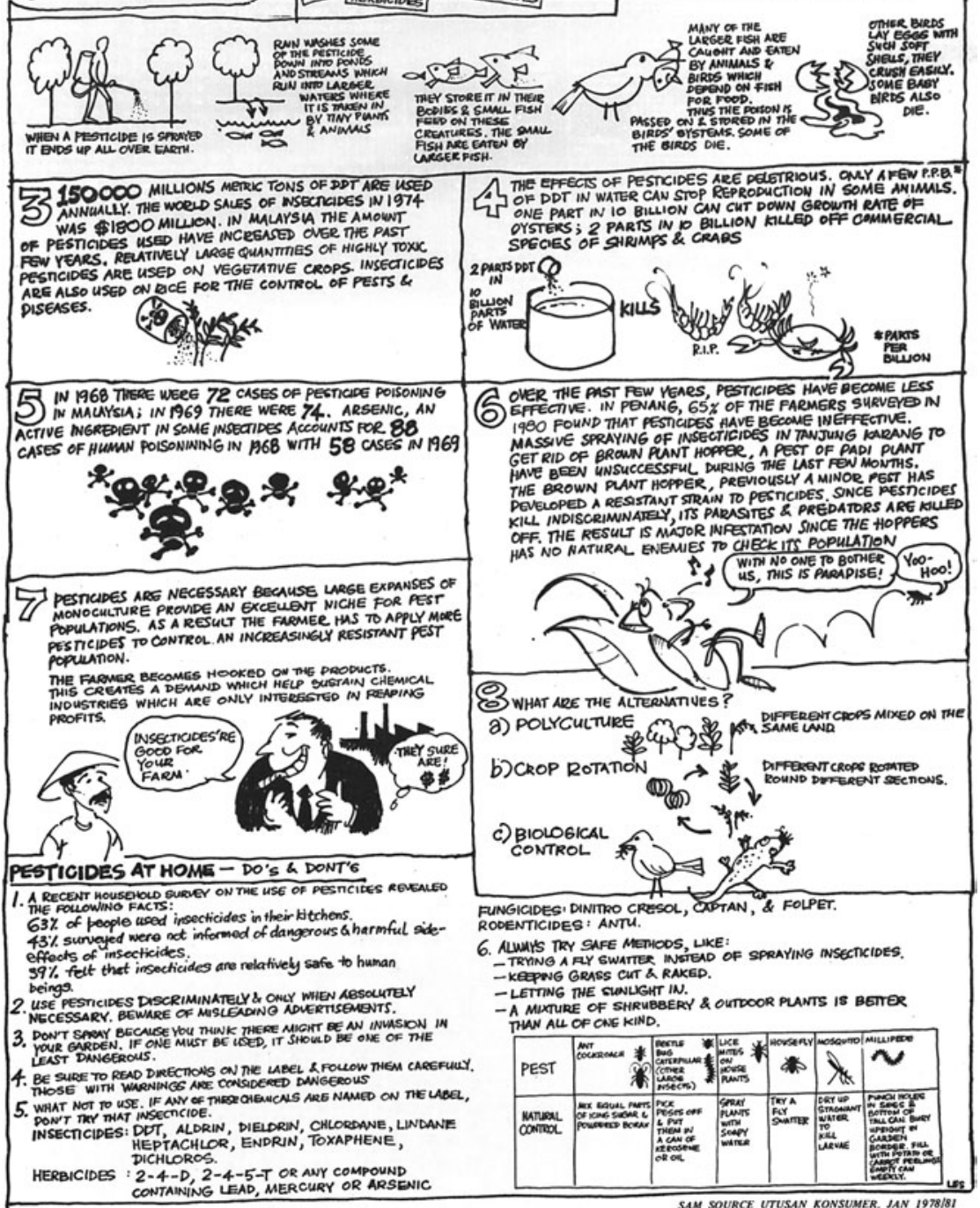

Figure r. "Dangers of Pesticides". This cartoon-style poster giving general information on the environmental problems and risks related to the wide-spread use of pesticides in agriculture is an example of the sort of social-movement campaigns CAP and, in this case, its sister organization Sahabat Alam Malaysia [Friends of the Earth Malaysia] organized in the I970s and I980s.

Detachable poster appended to the pamphlet "Pesticide Problems in a Developing Country - A Case Study of Malaysia" published by Sababat Alam Malaysia, I98I. 
remarkable if one compares it to the figure of 200,000 which represented the largest circulation for a daily newspaper in Malaysia at the time..$^{2}$

By this time, CAP's work was being directed to a whole series of cause célèbres, from the plight of Malaysian fishermen to rural market gardeners deprived of their traditional farming patterns, padi-farmers whose crops were destroyed by industrial pollution, or the indigenous (Orang Asli) populations pushed aside to make way for commercial logging. 53 CAP critiqued advertising and marketing practices, the portrayal of women in the media, and the inequities of a global trading system which enabled multinationals to engage in practices (such as the selling of dangerous pharmaceuticals) which had been banned elsewhere, while the environment remained a persistent concern. ${ }^{44}$ Accordingly, Idris argued that there needed "to be a radical rethinking of development concepts, economic strategies, even the concepts of law and justice, if the people are going to survive". 55

In 1987, he prophesied the apocalyptic nature of Malaysian development under the title, "Stop the train, we're going to crash", and CAP's Research Director, Martin Khor, launched a broad-ranging assessment of Malaysia thirty years after independence, highlighting the restrictions on democracy, equality, and civil liberties, the absence of social justice measures within development programmes, and the diversion of resources away from the poor to self-glorifying and wasteful luxury projects. ${ }^{6}{ }^{6}$ To blame was the "businessman's government" whose politicians continued to divert the people with arguments about race, while engaging in corrupt practices themselves and adorning one another with state and federal honours awarded by the sultans. ${ }^{57}$ While the government promoted

52. Kemkumar Saviour Lopez, "Consumer Associations in Malaysia", in SCA, Proceedings of Law and the Consumer Conference (Kuala Lumpur, 1981), p. 33; Dexter and Troth Tiranti, People with a Purpose: The Consumers' Association of Penang (Penang, 1985), p. I5.

53. Ibid.; CAP, Crisis in Malaysian Fishing (Penang, 1977); CAP, The Malaysian Fisheries: A Diminishing Resource (Penang, 1977); E. Hong, Natives of Sarawak (Penang, I991); CAP, Padi Pollution in Kuala Kedah (Penang, 1978).

54. CAP, Selling Dreams: How Advertising Misleads Us (Penang, 1986), p. I03; Utusan Konsumer, I 8 (May 1984), p. I; CAP, The Other Baby Killer (Penang, I981), p. I4; CAP, Breastfeeding: The Best Start in Life (Penang, 1990); CAP, Drugs and the Third World: Phenylbutazone and Oxyphenbutazone Sale and Hazards - A Malaysian Study (Penang, 1984); CAP, Pesticide Problems, Legislation and Consumer Action in the Third World: The Malaysian Experience (Penang, 1985); CAP, Battle for the Environment: The Malaysian Experience (Penang, 1974); CAP, The Malaysian Environment in Crisis: Selections From Press Cuttings (Penang, 1978); CAP and Institut Masyarakat, Appropriate Technology, Culture and Lifestyle in Development: Declarations and Resolutions of Seminar, November I98I (Penang, 1982); CAP, Padi Pollution in Kuala Kedah (Penang, 1978); Evelyn Hong (ed.), Malaysian Women: Problems and Issues (Penang, I983); CAP, Rape in Malaysia (Penang, 1988).

55. Utusan Konsumer, I55 (June 1987), p. I0; S.M. Mohamed Idris, Malaysian Consumers and Development (Penang, I986).

56. Utusan Konsumer, i 59 (October 1987), pp. I-I4.

57. S.M. Mohamed Idris, For a Sane, Green Future (Penang, I990), pp. 17, 88-95. 
prestige projects such as the North-South Highway and Kuala Lumpur International Airport, CAP emphasized instead the traditional Malaysian customs and values associated with kampung (village) life and the indigenous forms of technology as found in the Malay house. ${ }^{58}$

One explanation for CAP's participation in such a wide range of debates lies in the absence of other established civil society organizations in Malaysia in the I970s. This was a situation remarkably different to that faced by Western consumer groups and CAP simply found itself expanding into new areas as there were few other groups campaigning on these issues. But as its scope and vision grew, CAP developed a model of consumer protection or the consumer interest which gave it a distinct, and influential, identity and which provided the benchmark for the work of all other consumer activists in the country. After the establishment of FOMCA in 1973 , consumer organizations appeared in every Malaysian state, ending with the Consumers' Association of Sabah in I980. Most of these associations have suffered from a limited membership base but this has not put consumer leaders off trying to become a mass-based organization; nor has their funding from government sources deterred many from following the lead of CAP. Several of the initiatives in the I 970 s and I980s attempted to take consumerism to the grassroots all around Malaysia. 59

When Bishan Singh was elected President of FOMCA in I98I he attempted to develop consumerism into a professional movement with sufficient resources to free it from the need for state assistance which had tarnished its reputation for independence of action. This led FOMCA, in I 984 , to commit itself to a hopelessly broad set of objectives: to "inform, educate and protect the consumer; promote socio-economic and environmental justice, eradicate poverty and promote a 'need-oriented' development, promote racial unity, peace and people's self-reliance, and ensure that the government remains at all times the servant of the people and not its master" ${ }^{60}$ Bishan's inspirations clearly came from CAP, though he also drew on the campaigns of IOCU's regional office in Penang, headed by this time by CAP's Anwar Fazal, particularly their issue-based global

58. Budi Rusindah, Kampung Diary (Penang, 1992), p. 7; Lim Jee Yuan, The Malay House: Rediscovering Malaysia's Indigenous Shelter System (Penang, 1987); Joel S. Kahn, "Class, Ethnicity and Diversity: Some Remarks on Malay Culture in Malaysia", in Kahn and Loh, Fragmented Vision, pp. 158-178.

59. Interview with Bishan Singh, 27 November 2003; Beritta Pengganu, 2 (1988), pp. I-I2; interview with Sothi Rachagan, Io November 2003; SCA, Law and the Consumer: Report of Seminar Proceedings, Io October 1982, University of Malaya (Petaling Jaya, I982), pp. 8-I4; Sothi Rachagan and Tunku Shamsul Bahrin, Development Without Destruction: The Need for a Pragmatic Forest Policy in Malaysia (Petaling Jaya, I985); interview with M. Nadarajah, Io April 2004 .

60. FOMCA, Organising for Change: FOMCA's Five Year Integrated Consumer Protection Programme (I June 1984-3 I May 1989) and an Organisational Profile (Kuala Lumpur, I984), p. 2. 
networks (on pesticides, pharmaceuticals, breast-milk substitutes) which he attempted to re-create at the national level. ${ }^{6}$ Bishan's vision was unrealizable if not naïve given the limited rescources available to FOMCA, yet after the end of his presidency in 1988, his goals remained reference points for a socially-oriented FOMCA leadership and FOMCA continued to address the same type of environmental issues as examined by CAP. ${ }^{62}$

For all Bishan's efforts to bring the alternative development model of CAP to the consumer movement as a whole, though, FOMCA's more tangible successes came through its advocacy and legal work. It achieved gains in extending consumer protection legislation, especially the establishment of Small Claims Courts in 1987, and it was able to build on its relationship with government to increase its representative role. ${ }^{63}$ Such access to the government has enabled FOMCA to maintain a prominent public role, so much so that by the r990s, Hamdan Adnan, and assisted by his contacts in the media, became a well-known public figure in Malaysian life, competing even with the renown of CAP's S.M. Mohamed Idris. ${ }^{64}$

\section{CONSUMERISM AND THE STATE}

It is this close relationship with government which brings out the other characteristic of Malaysian civil society. If CAP chose to resist hegemonic understandings of development in the I970s and I980s, FOMCA also had to adopt a "consensual and collaborative" role. The government has sought to influence the work of FOMCA through its funding and the government's commitment to an effective consumerism must be questioned. For instance, the Consumer Affairs Division only maintained a staff of five until I990, which then increased to just sixteen following the

6r. Bishan Singh and Maggie Wellington, Promotion of Socio-Economic Justice and Community Development through Consumerism: Report No. 3, I June 1985-3 I December 1985 (Kuala Lumpur, 1986); The Co-ordinator [in-house newsletter of FOMCA], nos I0-15, I985; Bishan Singh and Maggie Wellington, Promotion of Socio-Economic Justice and Community Development through Consumerism: Report No. 5, I June 1986-3 I December 1986 (Kuala Lumpur, 1987), p. 2.

62. Bishan Singh, Consumerism as an Alternative Strategy for Development and FOMCA's 3Year Programme (Kuala Lumpur, 1987); FOMCA, The Right to a Healthy Environment: Environmental Evaluation Report, 1989-1990 (Kuala Lumpur, 1990); idem, Earth Day Report (Kuala Lumpur, 1990); CAP, Wasted Lives: Radioactive Poisoning in Bukit Merab (Penang, 1993).

63. Bishan Singh and Joe Selvaretnam, Community Development and Consumer Protection Through Legal Literacy: Report No. 6, I April I986-3 I July I 986 (Kuala Lumpur, 1986); Chee Yoke Ling, "Summary of the Main Consumer Protection Legislation in Malaysia", in FOMCA, The Law and the Malaysian Consumer, pp. 32-35; Consumer Digest: A Magazine for Malaysian Consumers' Associations, I (June 2002), pp. 7-8.

64. Interview with Mohammed Hamdan Adnan, 28 November 2003; interview with Marimuthu Nadason, I4 November 2003. 
establishment of the Ministry of Domestic Trade and Consumer Affairs. ${ }^{65}$ At other times, when FOMCA has appeared more critical of the state, government officials have publicly disparaged consumerism and have threatened to cut the limited funding that it has provided to state consumer organizations. ${ }^{66}$ FOMCA has had to play a delicate balancing act in its relations with government.

Hamdan has stressed repeatedly the benefits of cooperation rather than confrontation, and Bishan frequently mentioned that the government found FOMCA to be one of the "moderates" and was, therefore, by implication, a much more useful organization for the state to do business with than other civil society organizations. ${ }^{67} \mathrm{Hamdan}$ has used his voice in the press to present himself as the voice of reason and conciliation and has gone so far as to praise Mahathir's "brave and radical" stance in dealing with the currency speculation at the height of the economic crisis in the late I990s. Such political toadying is perhaps understandable within the context of Mahathir's authoritarianism, but for others in the NGO movement, they are the symbols of cooption and they have, in particular, provided further justification for CAP's continued decision not to join FOMCA.

Yet the state does not merely make its presence felt through the withholding of government funding: far more coercive measures have been open to it in south-east Asia. One unusual measure of the influence of CAP within civil society is the inclusion of its staff on the list of those to be detained under the Internal Security Act drawn up by Mahathir in 1987. In Operasi Lallang, Mahathir launched a crackdown on his political opponents and members of civil-society groups which saw the arrest of over roo members of the political opposition, the Chinese education movement, and prominent NGO activists such as Aliran's President, Chandra Muzaffar. Also included was CAP's legal officer, Meena Rahman, and SAM's activist in Sarawak, Harrison Ngau, while CAP's research director, Martin Khor (at the time in Europe) and even Idris himself were rumoured to have been on the original list. ${ }^{68}$ Mahathir's intention had been to send out a warning to what he perceived to be an irritating NGO community and to nip in the bud an increasingly vociferous anti-development agenda. ${ }^{69}$

65. New Straits Times, 20 November 1990.

66. Sun, I April I997; New Straits Times, 3 I March 1997; Malay Mail, 8 May I998; Star, I I June 1998; New Straits Times, I I June 1998.

67. Hamdan Adnan, Understanding Consumerism, p. I9.

68. Interview with Meena Raman, conducted by Jeremy Seabrook, I998[?]; interview with Meena Raman, I6 April 2004; Committee Against Repression in the Pacific and Asia (CARPA), Tangled Web: Dissent, Deterrence and the 27 October 1987 Crackdown in Malaysia (Kuala Lumpur, I988).

69. Jomo, K.S., "Race, Religion and Repression: 'National Security' and the Insecurity of the Regime”, in CARPA, Tangled Web, p. 6; Means, Malaysian Politics. 
It has been relatively easy for commentators on Malaysian consumerism to point to instances of cooption, especially since FOMCA has relied so heavily on continued government funding. What is more difficult to assess is the impact of the authoritarianism associated with Operasi Lallang upon the activities of NGOs. Certainly, CAP officers themselves deny that the arrests had any bearing on their activities, ${ }^{70}$ and in the late 1980 s and 19905 CAP campaigned on the same range of issues (squatters' rights, land reforms, pesticide use, rape laws, business malpractices, the environment, pollution). $7^{71}$ What did change, though, was the tone of CAP's critique. The style used in Utusan Konsumer became less confrontational and as early as I988, although the wider problems of development were still there, the campaigns were no longer screamed from the headlines and the newspaper seemed to find more space for the established consumer concerns of things to be aware of in the purchase of goods and commodities. Moreover, the blame CAP attributed to the problems of development moved from Mahathir's own government's policies to the wider international economy. At a conference organized with Third World Network (another offshoot of CAP which Idris also presides over), the blame for "the violation of economic, social and cultural rights of Third World Peoples" lay not so much with a government which had detained without trial several of Idris's colleagues, but international law, a system which was held to legitimize "the domination and manipulation of the Third World by industrialized countries." 72

CAP had for some time turned its attention to the global situation, and there existed within Idris himself a longstanding anti-colonial discourse which stretched back to his own political education through Indian and Pakistani nationalism. But whether due to the attentions of the government, or through a wider realization among NGO activists as to the issues arising out of the structures of global economic governance, CAP increasingly turned its attention to international affairs, adopting a Third World perspective which would not be incompatible with Mahathir's own attacks on the International Monetary Fund, the World Bank, and the World Trade Organization in the late I990s at the height of the Asian financial crisis. ${ }^{73}$

70. Interview with Meena Raman, I6 April 2004; interview with S.M. Mohamed Idris, I 6 April 2004 .

7I. Meena Raman and Thayalan Muniandy, "The Legal Centre of the Consumers' Association of Penang: Its History, Activities and Future Programme”, paper presented to TWN Seminar, "Expanding Public Interest Legal Activities", is-19 January 1988.

72. Utusan Konsumer, I66 (May 1988), p. I8.

73. CAP, Understanding Global Organisations: How They Act Against People's Interests (Penang, 2003); Martin Khor, "Value for People: The Potential Role of a Consumer Movement in the Third World", paper held in archives of Consumers' Association of Penang, n.d.; CAP, The Consumers Association of Penang (Penang, 1987); Meena Raman, "Comparative Analysis of Consumer Issues in Malaysia and Other Countries", paper presented at a meeting of the Malaysian Consumer Council, ro December 1994 (private papers of Meena Raman). 
Through the work of Martin Khor and the Third World Network (TWN) CAP has become tied to a "Southern" perspective on global trade which Mahathir used to defend his own protection of the Malaysian economy. ${ }^{74}$

To this extent, CAP's international stance is but one of many voices in a wider anti-globalization movement. And in redirecting its point of criticism from national to international governance, although cooption would be too strong a term, it is not unreasonable to argue that CAP has found a way to continue expressing its politics of consumption in a difficult political situation. But it also further problematizes the relationship between NGOs and the state, especially if we compare its politics of accommodation with Mahathir to the organizations more commonly claimed to have been coopted; i.e. FOMCA.

Underfunded by the state, FOMCA has nevertheless been able to find a role and a voice for itself not dissimilar to that of more obviously independent civil society bodies. It has used its contacts with the media to publicize a series of abuses of the consumer in the market. ${ }^{75}$ It has also realized its own limitations in terms of personnel and resources, encouraging networking with other NGOs while CAP has preferred to follow its own path or develop its own links through its sister organizations. For instance, in I993 FOMCA established a National NGO Resource Centre, with assistance from the United Nations Development Programme and the Asia Foundation, and it continued to work, whenever possible, with other NGOs such as through the Malaysian Environment and Conservation Network, in the fight against the Indah Water Konsortium, and in the "Abolish ISA Now!" campaign of $2000 . .^{76}$

At the same time, another consumer organization has also risen to prominence. Inspired by CAP's work with poor consumers, Josie Fernandez (sister of Irene Fernandez) established the Education and Research Association for Consumers (ERA) in 1987. It engaged in many of the same projects as CAP, developing health camps for the Orang Asli, working with villages to ensure access to basic consumer amenities, promoting alternative organic farming methods which eschewed pesticides, highlighting environmental problems and working with women dealing with poverty, low wages, desertion by spouses, domestic violence, and the abuse of their "human dignity" ${ }^{77}$ ERA's activities were not

74. Martin Khor, Globalisation and the South: Some Critical Issues (Penang, 200I); Gomez and Jomo, Malaysia"s Political Economy; Consumers International, [...] And Our Rice Pots Are Empty: The Social Costs of the Economic Crisis (Penang, 1998); Jomo K.S., M Way: Mahathir's Economic Legacy (Kuala Lumpur, 2003).

75. Interview with Mohammed Hamdan Adnan, 28 November 2003; Nazatul Izma, "The Man from La Mancha”, Malaysian Business, I6 July 1995, pp. 42-43; Yusof Ghani, "One Tough Customer", Sun Magazine, 8 October I997, p. I 2.

76. Lim Teck Ghee, "Non-Governmental Organisations", p. i7i; Fernandez, Contested Space, p. 59; FOMCA, Secretariat Report, 1993 (Kuala Lumpur, I994); Malay Mail, 9 September 1993. 77. ERA, Annual Report, I990, pp. 6-7. 
without the problems which one might expect to beset a group of informed amateurs dealing with complex problems, but the organization did at least represent a shift in the centre of gravity away from Penang. ${ }^{78}$

Significantly, while FOMCA, CAP or SAM had not signed the main protest petition against the arrests of Operation Lallang, ERA had immediately done so. ${ }^{79}$ Clearly, for the government-funded FOMCA to have signed the petition would have amounted to bureaucratic suicide. But the absence of a signature from CAP attests to the other forms of influence the Malaysian authorities have been able to assert. However, in the subsequent activities of both CAP and FOMCA, evidence of both cooption and independence is available. As Rodan and others have argued of south-east Asia, the issue is not so much about the role of the state in preventing the development of civil society. Rather, it is about how different forms of political space have been created by urban, educated and in this case consumer - activists who have had to operate in a variety of political and institutional contexts.

\section{CONSUMERISM AND OTHER SOCIAL MOVEMENTS}

At the same time that CAP, FOMCA and ERA have negotiated their way around a changing state, they have also worked amidst a changing civil society. Here, Malaysia has not avoided the trends in civil society organizing which have affected democratizing states in south-east Asia more generally since the I980s. Although not comparable to the flourishing of the NGO community in neighbouring states such as Thailand and the Philippines, where around 400,000 currently operate in each country, by 1996 there were, in Malaysia, 28,2 I 9 registered NGOs, of which 4, I66 were religious bodies, 3,806 were concerned with social and recreational matters, 3,500 were for sports, and 2,587 were social welfare organizations. ${ }^{80}$ While only a small percentage of this figure could be regarded as actual advocacy-oriented NGOs along the lines of CAP, it does nevertheless mean that the consumer voice must now compete with many hundreds addressing a whole range of developmental issues. Thus, while CAP's critique has turned away from the state and towards the international community, it has done so at a time when competing forms of expertise have provided their own solutions. In this sense, it would make it far more difficult to assume the leadership role in civil society as it once had done in the r 970 and r 980 s.

In particular, there has been a shift in the dominant discourses used by

78. ERA, Annual Report, I996; interview with Josie Fernandez, 8 December 2003.

79. CARPA, Tangled Web, pp. 89-90.

80. Fernandez, Contested Space, p. Iо; Meredith Weiss, "Malaysian NGOs: History, Legal

Framework and Characteristics", in Weiss and Hassan, Social Movements in Malaysia, pp. 17-44. 
both the state and NGOs which has seen the substitution of consumer concerns with those of a human rights agenda. In the I970s, the developmental policies of the New Economic Policy had provided the hegemonic language through which civil society operated and against which CAP found itself resisting: UMNO's promotion of a developmental discourse opened up new opportunities for debate, discussion and opposition within which CAP found itself at the forefront, especially since such developmentalism was bound up with a politics grounded in ethnicity which CAP was attempting to transcend. Francis Loh has suggested that in Malaysian society, broadly defined, the New Economic Policy's focus on race has today given way to an emphasis on "developmentalism" by which he means the promotion of mass consumer culture. $^{8 \mathrm{I}}$

However, one could argue that NGOs in the I970s were reacting against a particular model of economic development being promoted by the government. Since then, UMNO - and Mahathir in particular - have rooted these economic policies within a framework of "Asian values" which, it might be argued, have forced civil society to focus attention on the discussion of human rights as a bulwark against the perceived injustices which Asian values could confer on the general citizenry. According to Khoo Boo Teik, Mahathir and Lee Kuan Yew of Singapore have stressed the inappropriateness of individualistic Western liberal models of political rights. These two leaders have contended that Asians were communalist rather than individualist, have demonstrated a "cultural predisposition towards stable leadership rather than political pluralism" and have showed "a proclivity to consensus as opposed to a tendency towards dissent or confrontation": "Asians, therefore, preferred a strong, even harsh, government, so long as the government's policies and actions continued to deliver economic prosperity." 82 In contrast, NGOs have sought to defend such rights, not least because of the clear abuses of power contained within the Internal Security Act and which have continued to motivate human rights activists in organizations such as Suaram and Tenaganita. And for the consumer movement, there has even been an attempt to extend such Western liberal rights - into the economic, social and cultural sphere - which directly challenges the assumption of the proponents of Asian values that Asians willingly trade off these rights for a higher standard of living.

In Malaysia, though, as elsewhere, the focus on rights and values has not

8I. Francis Loh Kok Wah, "Towards a New Politics of Fragmentation and Contestation", in Francis Loh Kok Wah and Johan Saravanamuttu (eds), New Politics in Malaysia (Singapore, 2003), pp. 253-282, 26I; Francis Loh Kok Wah, "Developmentalism and the Limits of Democratic Discourse", in Francis Loh Kok Wah and Khoo Boo Teik (eds), Democracy in Malaysia: Discourses and Practices (Richmond, 2002), pp. 19-50.

82. Khoo Boo Teik, Beyond Mahathir, p. 25. 
been without its contradictions and problems. The Asian values position, even if promoted by an authoritarian state, has also found its supporters within civil society. Certainly, Islamic-based organizations have shared in this critique of Western liberalism and have promoted instead the communal nature of Asian values. Chandra Muzaffar, formerly of Aliran and now leader of the International Movement for a Just World (originally created with Anwar Fazal and S.M. Mohamed Idris of CAP) has called for a human rights model which encompasses not only civil and political rights but also social, cultural and economic rights, at the same focusing on the meaning of "human dignity" in which human rights are rooted in a spiritual and moral vision of the human being derived from religion. ${ }^{83}$

CAP, too, has articulated a concern for consumer rights which both challenges and affirms the basic assumptions of the Asian values protagonists, while problematizing its relationship to a human rights discourse which perhaps best encapsulates the modes of thought which make up the "epistemic community" of international NGO activists. ${ }^{84}$ For instance, in 1988, CAP criticized the portrayal of homosexuality in advertising for the offence it might cause to the majority of Malaysians. ${ }^{85}$ The institutions of the global economic order have also been condemned, not only for their effects on people's livelihoods, but for the onslaught mass consumption is said to have launched on traditional Malaysian values. But whereas CAP used to criticize the government for its assistance to such economic forces, by the late I990s, it could "feel confident that this Government's concern for the people will generate a will to initiate a review of its policies and laws which reflect these critical values and concerns." ${ }^{\prime 6}$ Both Mahathir and Idris adopted an anti-Western set of arguments in defence of a notion of Malaysian - or Asian - ways of life, though the motivation behind the two men's positions might not have been equally sincere. For Idris, the opening of Malaysia's doors to drugs, Hollywood, pop music, magazines, and all the other symbols of consumer society, have destroyed the old communal way of life giving way to a meaningless individualism. Somewhat misty-eyed, he celebrates what he believes were the ways of life and values of his own, or his parent's generation. ${ }^{87}$

Yet, for all the corruption and crass materialism of Malaysia's political elites, such nostalgia fits into their own idealized notions of Malaysian

83. Chandra Muzaffar, Rights, Religion and Reform: Enhacing Human Dignity through Spiritual and Moral Transformation (London, 2002), p. 45.

84. John Boli and George M. Thomas, "INGOs and the Organisation of World Culture", in idem, Constructing World Culture: International Nongovernmental Organisations since I875 (Stanford, CA, I999), pp. I3-49.

85. Utusan Konsumer, I62 (January 1988), p. I7.

86. Utusan Konsumer, 28 (January 1998), p. 3.

87. Idris, Reflections on Malaysian Society, p. 80. 
society and the country's headlong and near-suicidal, traffic-logged rush along the North-South highway every Hari Raya to get back to the kampung of their parents and grandparents. CAP's rapprochement with Mahathir arose from the mutual desire to defend the East against the West, or the South against the North. It led to a desire by both to invoke a notion of Asian values (despite the complexity and marked differences within Malaysia's ethnic groups and cultures), such that CAP's defence of human rights has no longer been the absolute standard with which to measure the government's economic and social planning. ${ }^{88}$

Since the I990s, CAP has remained somewhat distant from the rest of the Malaysian consumer movement and, in its moralistic critique, it maintains a distinction from much of the rights-based rhetoric which has elsewhere pervaded Malaysian civil society. ERA and FOMCA, for instance, have been much less concerned with values (Asian or otherwise) and have rooted themselves firmly within a defence of human rights articulated by a whole variety of Malaysian NGOs. As with CAP, core consumer issues such as the problems of direct selling techniques, pyramid schemes and the costs of pharmaceuticals, have remained central components of ERA's work, while it has sought foreign funding for larger scale projects on the environment, sustainable development and food security. ${ }^{89}$ But it is human rights which have generated the most excitement within the organization over the last few years. Human rights have become one of its most prominent education programmes, for youths as well as adults, in short courses and workshops all around the country and it is the human rights desk which has been the most active..$^{90}$ It has also tried to position itself as a leading spokesbody on human rights, organizing workshops

88. Some examples of CAP's promotion of alternative values can be found in: CAP, Natural Wisdom: Stories and Reflections on Nature by the Ancients, Thinkers and Ecologists (Penang, 2003). 89. Chitra Nadarajah, A Biological Management Study of Bukit Larut and Its Surrounding, Perak, Malaysia (Petaling Jaya, I997); ERA, Annual Report, I998 (Petaling Jaya, I999), p. 9; The Sunday, 24 January 1999, p. I 8; Indrani Thuraisingham, “The Consumers' Perspective: A Brief Overview of the Malaysian Food Security Situation", paper presented to International Conference on ASEAN Food Security, Hanoi, 3-6 November 1998; ERA, National Consultation Conference on Food Security, Kuala Lumpur, 25-26 July 1998 (Petaling Jaya, 1998); Katherine Ann Francis, Biotechnology - Simplified (Petaling Jaya, 2003); ERA, Awareness Seminar: Introducing Codex Alimentarius (Petaling Jaya, 2003); G. Umakanthan (ed.), Assessing Food Security: A Micro-Study of 24 Villages in Malaysia (Petaling Jaya, 2002); ERA, National Agriculture Workshop: For a Successful Food Production Sector in Malaysia (Petaling Jaya, 200I); ERA, Annual Report, 200 I (Petaling Jaya, 2002); New Straits Times, 25 April I999; Sun, 2 May 1999; ERA, Annual Report, 200 I (Petaling Jaya, 2002), p. I0; Rokiah Alavi, TRIPS and Pharmacenticals: The Impact on Malysian Consumers (Petaling Jaya, 2003); Sivananthan Balan, Direct Selling: An Evaluation (Petaling Jaya, 2003); Bishan Singh, Consumer Education (Petaling Jaya, 2002); ERA, Understanding Malaysian Consumer Redress Mechanisms: Towards Dynamic, Progressive and Responsible Consumer Society (Petaling Jaya, 2004).

90. ERA, Minutes of the Fifteenth AGM, 4 February 200 I (Petaling Jaya, 200I); ERA, Annual Report, 2002 (Petaling Jaya, 2003), p. 9. 
with groups such as Tenaganita, Hakam and Suaram which have assessed and criticized the performance of the National Human Rights Commission, Subakam.9 ${ }^{\mathrm{I}}$

In a sense, the focus on rights is a recognition that the political identity of the consumer is no longer quite as radical or as all-encompassing as it had been in the I980s. ERA has used the language of human rights - especially economic, social and cultural rights - to justify its extension into a whole range of activities. It has argued that consumer rights are a fundamental part of the United Nations definition of economic, social and cultural rights and that if these rights are not realized in the lives of ordinary Malaysians then it follows that they have little chance of exercising their rights as consumers. But so too do consumer protections, it is claimed, offer some of the most basic safeguards against the abuse of economic and social rights. Consumer rights and human rights thus become indistinguishable, in the minds of a new generation of consumer activist at least, and it legitimates the involvement of FOMCA and ERA in a whole range of activities. Over the last few years, ERA has positioned itself, if not an expert investigator into a whole range of social justice issues, then at least a principal educator of everybody as consumers in awareness of these issues. It has published handbooks on domestic violence to help women know their rights and on the role of Islam within an international human rights framework. ${ }^{2}$ It has pushed for the government to recognize the International Criminal Court and, as part of its large-scale project to empower poor Indian women, it has set up ten community centres around the country.93 The location of consumerism within the human rights framework has enabled it to achieve a national prominence quite spectacular for an organization which remains very small and limited to just a handful of full-time staff, but it has also pointed to certain limits as better resourced and well-established human rights NGOs such as Suaram still maintain a higher public profile on these topics.

The institutional framework within which FOMCA has had to operate has restricted it from having the same degree of operational freedom as ERA, though it has, nevertheless, incorporated much of the human rights framework into its operating policies, not least because of

91. ERA, Proceedings of Forum on Understanding the Human Rights Commission Act I999 (Petaling Jaya, 2002); ERA, Proceedings of the National Consultation on "SUHAKAM: After One Year" (Petaling Jaya, 2002); ERA, National Consultation on Subakam after 2 Years: "How has the Commission Played a Role in Promoting and Protecting Human Rights in Malaysia?" (Petaling Jaya, 2003).

92. ERA, A Handbook on Understanding Domestic Violence (Petaling Jaya, 2003); ERA, Understanding Human Rights and Islam: Motivation, Ideology and Relevance in a Contemporary Society (Petaling Jaya, 2003).

93. ERA, Programme: Workshop on the International Criminal Court, 6-8 December 2003 (Petaling Jaya, 2003); http://www.eraconsumer.org. 
the crossover in personnel between the two over the last decade. Accordingly, FOMCA has insisted that the satisfaction of basic needs represents one of the most fundamental of all consumer and human rights. Its "basic needs paradigm" has consisted of campaigning to improve the quality of life by increasing access to food, shelter, clothing, sanitation, health care and food while adopting a sustainability approach which aims to protect "the needs of future generations in the consumer decisions of today". ${ }^{4}$ It has emphasized its role as a grassroots organization, fighting for "the weak and powerless in society", and it has highlighted issues such as the extortionate billing system of the Indah Water Konsortium and the privatization of health care in order to touch on subjects of interest to all consumers. ${ }^{95}$ Therefore, and despite the middle-class, urban professional dominance of its membership, FOMCA still declares itself a "citizen's movement: it is about social justice and human rights. It is concerned with ensuring that all citizens, both present and future generations have what they need in order to survive comfortably and in safety." 96

This shift to a human-rights perspective has not been without consequence, particularly on the role of consumerism in Malaysia and in its relations to other social movements. While human rights have clearly worked as a mobilizing agenda for civil society generally, it is less clear that it has worked for the consumer movement. Firstly, for CAP, it has meant the organization has sought to promote alternative value frameworks in opposition to what it sees as the Westernization inherent to rights-based rhetoric. Unfortunately, such a position has the potential to alienate it from other NGOs focused on the defence of rights, and while the defence of overtly politically rights is not so controversial, the defence of consumer rights is more problematic. CAP has resorted to a defensive attack against the West which has had much sympathy across Malaysia and the developing world more generally. But its invocations of traditional ways of life rest uncomfortably with the pursuit of mass consumption enjoyed by a new generation of Malaysians keen to enjoy the fruits of their hard labour. ${ }^{77}$ It has resulted in an attack on a whole variety of "Western" goods which CAP believes damages the physical, emotional and social health of the people, but which goes against the desires of the vast majority of consumers if the statistics of these goods' consumption is anything to go

94. Josie, Contested Space, p. Io2.

95. New Straits Times, 24 July 1997; I3 August 1997.

96. http://www.fomca.org.my/stater.htm

97. Rokiah Talib, "Malaysia: Power Shifts and the Matrix of Consumption", in Chua BengHuat (ed.), Consumption in Asia: Lifestyles and Identities (London: Routledge, 2000), pp. 35 -60; Antonio L. Rappa, Modernity and Consumption: Theory, Politics and the Public in Singapore and Malaysia (Singapore, 2002); Ziauddin Sardar, The Consumption of Kuala Lumpur (London, 2000). 
by. ${ }^{98}$ While Asian values have their appeal in the attacks they can lead to on the perceived power of western nations and the imposition of rights-based frameworks, their relevancy is called into question once consumers have been urged to adopt them in their ordinary life patterns. CAP could thus well find itself fighting the trends of consumer behaviour while missing out on a defence of human rights which has made organizations such as Suaram and Aliran so prominent in recent years.

Secondly, for FOMCA and ERA, which have attempted to concentrate on consumer rights as human rights, similar problems of irrelevance are apparent. ERA and FOMCA have emphasized the human-rights element of their work in order to remain players in the game of civil society, though in doing so they very much follow the lead provided by other NGOs which have greater skills and resources focused on dealing with human rights. To root consumerism in a human-rights framework is, in a sense, to acknowledge that the consumer movement can no longer enjoy the prominence once attributed to CAP and that the discourse of human rights is far more suited to dealing with the problems facing contemporary Malaysians than the alternative consumerist model of development propounded in the I970s and I980s.

Indeed, Malaysian consumer activists are today doubtful as to whether they would re-start their careers as consumer activists. CAP's Anwar Fazal has gone on to establish or involve himself in a whole range of activities, from the Sustainable Penang Initiative, the World Alliance on Breastfeeding Action, the Taiping Peace Initiative, and, with S.M. Mohamed Idris, Citizens International. ${ }^{9}$ Similarly, Josie Fernandez has questioned the wider significance of contemporary consumerism, implying it has become less a movement in the sense of the success enjoyed by the more prominent human rights, gender equity, workers' rights, and environmental campaigns and perhaps "merely a pressure group specifically to address market place concerns". ${ }^{100}$ M. Nadarajah, education officer for the SCA in the I980s, has claimed the consumer movement cannot adequately deal with the problems of over-consumption. ${ }^{101}$ Before his death at the end of 2006,

98. CAP has recently published dozens of such pamphlets. See, for instance: CAP, Fashion That Hurts (Penang, 2003); CAP, Cancer-Causing Chemicals in Cosmetics and Daily Use Products (Penang, 200I).

99. Interview with Anwar Fazal, I7 April 2004; Anwar Fazal, Consumers in the New Millennium: Back to Basics (Kuala Lumpur, 200I); Sarah Amin, Nurturing the Future: Our First Five Years (Penang, 1996); Lakshmi Menon, The Breastfeeding Movement: A Sourcebook (Penang, 2003); "Backgrounder on Anwar Fazal: 'The Citizen Activist', Anwar Fazal's private papers; Sustainable Penang Initiative, Penang People's Report, I999 (Penang, 1999).

ı००. F. Josie, "Consumer Protection in Asia: The Challenges Ahead", Journal of Development Communication, I2:I (200I), p. 42.

ıог. M. Nadarajah, "Rethinking Asian Consumerism: Some Preliminary Thoughts", in idem, Another Malaysia is Possible and Other Essays: Writings on Culture and Politics for a Sustainable World (Kuala Lumpur, 2004), p. 2 I7; interview with M Nadarajah, Io April 2004. 
Bishan Singh drifted away from the consumer movement believing it to be a means only to "fine-tune" rather than overhaul the existing social and economic system. ${ }^{102}$ Instead, he focused his attention on sustainability questions through his Management Institute for Social Change and the Sustainable Development Network. ${ }^{103}$ And, interviewed just prior to becoming the President of FOMCA when he still headed ERA, Marimuthu Nadason admitted that were he to start his civil society career all over again, it is likely he would join another type of campaign NGO than that of a consumers' association. ${ }^{104}$

\section{MALAYSIA AND THE INTERNATIONAL CONSUMER MOVEMENT}

At this point, some conclusions are necessary as to the history of the consumer movement within Malaysia. The above narrative suggests that consumerism might best be rooted in a specific historical moment of Malaysian development. Clearly, the tremendous growth in civil society organizations since the I 980 s could only serve to eclipse the influence of the consumer movement. But the appeal of consumerism - to the Malaysian public as the defender of its rights and to civil society as the generator of ideas - was strongest over the two decades of the New Economic Policy. During this time, many Malaysians began to experience affluence for the first time yet turned to CAP to guide them through a more complex marketplace, just as Western consumers, raised in the Depression era of the I930s, flocked to the consumer associations which sprang up during the period of post-World-War-II reconstruction in the I950s. ${ }^{105}$ Like Western consumers, too, Malaysians were attracted to the attention CAP gave to those left behind in the race to achieve higher economic growth, especially as it addressed concerns common to all ethnic groups and which therefore required non-communalist solutions which could not be found in the affirmative action policies of UMNO. According to consumer activists themselves, during this period "CAP's objectives and values [...] influenced the wider society, and have been absorbed into the common wisdom". ${ }^{\circ 06}$ Anwar Fazal has even cheekily suggested that so attractive have the actions of CAP been that even the ruling National Front adopted "the symbol of CAP as its emblem: the scales, with its

I02. Interview with Bishan Singh, 27 November 2003; Bishan Singh, The Consumer Movement and the Challenge for the New Millennium (Kuala Lumpur, 200I).

I03. Idem, The Quest for Sustainable Development (Kuantan, 2003); MINSOC, Learning in MINSOC: Reflecting on Social Change and Sustainable Development (Kuantan, 2002).

I04. Interview with Marimuthu Nadason, I4 November 2003.

105. Hilton, Consumerism in Twentieth-Century Britain.

I06. Interview with Lim Jee Juan, conducted by Jeremy Seabrook, I998. 


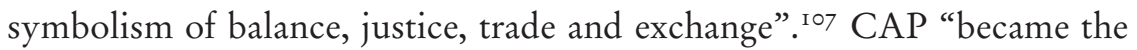
firstly broadly based development NGO in the country, dealing with local, national and global issues". ${ }^{\text {ro8 }}$

During this time the consumer movement was rather successful in acting as a leading NGO. Prior to the mid-r980s, CAP in particular was able to offer a range of practical and discursive alternatives to the dominant development model. With a more recent shift to a language of rights and values, all three of the main consumer organizations have contributed to ongoing debates about the rights of all consumers to share in the abundance promised by economic growth. At times, the state has sought to position consumerism as an oppositional and "anti-developmental" voice, else has tried to coopt its leaders and agendas, but it is nevertheless the case that the various agendas of the consumer movement have found themselves discussed at the heart of the federal government. Indeed, in 2002, the Malaysian government launched a National Consumer Policy, a central plank of which was the drawing up of a Consumer Master Plan for the period 2003-2013. ${ }^{109}$ This both seemed to demonstrate the centrality of consumer concerns to the Malaysian government but also the ability of NGOs to place their own agendas within official policy, despite the ability of the state to influence the dynamics of civil society.

This should not, of course, detract from an appreciation of the weaknesses and problems of the consumer movement. In addition to those already discussed about the relationship with the state and other social movements, the split between CAP and FOMCA has persisted and one can only speculate as to what might have been the potential further influence of a unified consumer movement. For all its protestations to be a people's organization, FOMCA has never been able to become a genuine grassroots movement which would have enabled it to break its financial ties with the state. It has never enjoyed the same resources as CAP which has been able to rely on overseas grants and the sale of its publications to fund its activities.

Yet in rooting consumerism to a significant, if overlooked, period in the historical development of Malaysia's civil society, the nature of the politics of consumption articulated must also be acknowledged. The history of the Malaysian consumer movement cannot be concluded without some brief remarks as to its impact on international consumerism. When Anwar Fazal was appointed to be IOCU's first regional director in Penang in 1974, he took many of the issues central to the work of CAP and placed them at the forefront of IOCU's campaigns. Prior to the I970s, IOCU had largely focused on increasing its

I07. Interview with Anwar Fazal, conducted by Jeremy Seabrook, I7 July 1997.

108. Ibid.

I09. Josie Fernandez, The Consumer Master Plan, 2003-2013 (Kuala Lumpur, 2002). 
representative role at the UN and promoting basic consumer rights to choice, redress, representation and information. From the I970s, though, IOCU embarked upon an agenda more relevant to the majority of the world's poor consumers who had to cope with the problems arising out of consumer detriment rather than consumer plenty. This was reflected in its operational philosophy as the right to basic needs was included in its list of eight fundamental consumer rights.

This is not to claim that IOCU did not continue to promote consumer campaigns of interest to Western organizations. One of its most successful was the passing of the United Nations Guidelines on Consumer Protection in I985; this formed the basis for a model law on consumer protection which would be used to implement consumer protection regimes around the world similar to those created in North America and western Europe in the I960s and I970s. But many of its more high profile campaigns reflected the concerns of organizations such as CAP in Malaysia. Anwar Fazal in particular was keen to take the issues of poor quality pharmaceuticals, the inappropriate marketing of products and the damage to the consumer's environment to the international arena. In I978, he became ideally located to move quickly as the leader of the international movement. While remaining an employee of IOCU as its regional director, he was also elected to be its President, since he represented CAP on IOCU's governing council. As both instigator and executor of international consumer movement policy, he brought the concerns of CAP to global civil society. He developed a number of campaigning networks to focus on specific issues, linking the consumer movement with other NGOs. In 1979, IOCU instigated the International Baby Food Action Network to campaign against the sale of breast-milk substitutes. In I98I, Health Action International was established to campaign against certain of the activities of multinational pharmaceutical companies. And in 1982, Pesticide Action Network began to fight for the protection of both consumers and producers exposed to dangerous chemicals. Led and administered by IOCU, the networks brought together a variety of NGOs and enabled many smaller groups to have a say in which issues should be brought to the attention of the UN.

While IOCU was able to reach out to other social movements at the international level, it was also able to use its now established position on bodies such as the UN Economic and Social Council, the World Health Organization, the Food and Agriculture Office, and even the UN General Assembly to push for and obtain a number of regulatory measures. In the I980s, it succeeded in establishing a UN Consolidated List of Banned Products, an International Code of Marketing of Breast-milk Substitutes and various food standards contained in the WHO's Codex Alimentarius. It also worked with other NGOs and the UN Commission on Transnational Corporations to set out a Code of Conduct on Trans- 
national Corporations, though this proved ultimately unsuccessful following much resistance from the US government.

These considerations can only be adequately addressed elsewhere. ${ }^{\text {IIO }}$ The important point to note is that Malaysian consumer activists had a clear influence on the international agenda. Often this was because CAP articulated a set of concerns voiced by many other consumer groups in Southeast Asia. But more directly it was because of the transfer of personnel from CAP to IOCU's regional office in Penang: Fazal ultimately took many staff with him just the few hundred metres that at one point separated the offices of Malaysian consumerism from the centre of gravity of international consumerism. To an extent, this direct influence came to an end with the departure of Fazal from IOCU in I99I, but by this time there were many other developing world consumer organizations advocating a basic needs perspective. IOCU's Council now consisted of representatives of most western European states, but also of consumer organizations across Asia, Africa, and Latin America. Moreover, the Presidency remained in the global South, held in the early I990s by Erna Witoelar of the Indonesian consumers' movement. ${ }^{\text {II I }}$

These developing world consumer issues have simply been ignored by the historical and social scientific literature. Sociological and cultural studies have tended to focus on questions of identity, style and image, issues which arise only in societies of the affluent. Only relatively recently have some sociologists turned their attention away from the spectacular and toward the "ordinary". ${ }^{\mathrm{II} 2}$ Historical work which has looked directly at the political aspects of consumer society has also tended to focus on those already existing within - rather than those excluded from consumer society. Indeed, in two of the most recent works on the history of consumption, the focus remains distinctly American, whether because the account is specifically on that nation's consumer society or because the issues of the "Americanization" of Europe are being explored. ${ }^{113}$

If important correctives to this literature are to be made, further research on countries such as Malaysia is required. South-east Asia generally proves particularly useful for exploring necessitous consumption issues in rapidly changing societies through the I970s and I980s. By examining the consumer movement, many of the contradictions of the politics of

I Io. I will explore many of these issues in a forthcoming book on the history of the international consumer movement.

II I. IOCU, Consumer Power in the Nineties: Proceedings of the Thirteenth IOCU World Congress (The Hague, I99I), p. I I3.

I I 2. See, for instance, Jukka Gronow and Alan Warde (eds), Ordinary Consumption (London: Routledge, 200I). Also, Matthew Hilton, "The Banality of Consumption”, in Frank Trentmann and Kate Soper (eds), Consumption and Citizenship (London, forthcoming).

I I3. Victoria de Grazia, Irresistible Empire: America's Advance Through Twentieth-Century Europe (Cambridge, MA, 2005); Lizabeth Cohen, A Consumers' Republic: The Politics of Mass Consumption in Postwar America (New York, 2003). 
consumption can themselves be expanded upon, especially in the differences of the interests of poor and affluent consumers: for example, is the consumer interest about greater freedom of choice for the individual or greater access to markets for all potential consumers? But elsewhere, further studies are required of consumer organizing, such as in Latin America in the I980s. By the I990s, the attention of the international movement was firmly on developing grassroots consumer organizations across Africa. To some extent, this has been a success and it has meant the concerns of African consumers have been aired at international meetings, especially over questions of food sovereignty and the governance of world trade. If we are to understand better the issues of constructing a global consumer society, these movements of consumers provide an opportunity to further explore the politics of consumption from both a Northern and a Southern - but together, global - perspective. 